\title{
Perbandingan Algoritma Genetika dengan Algoritma Greedy Untuk Pencarian Rute Terpendek
}

\author{
Rizky Berlia Oktaviandi", M. Sadid Tafsirul Hadi**, Alanfansyah Ghozy Santoso ${ }^{* * *}$, Nova EI \\ Maidah**** \\ Program Studi Teknologi Informasi, Program Ilmu Komputer, Universitas Jember \\ berliarizkyy@gmail.com, ${ }^{* *}$ msadidt@gmail.com, ${ }^{* * *}$ alfansyahghozysans@gmail.com, ${ }^{* * * *}$ nova.pssi@unej.ac.id
}

\begin{abstract}
In everyday life we often travel from place to place. So that we need to consider the time and cost efficient. Therefore, accuracy is needed to determine the shortest path as a consideration in decision to show the path to be taken. The results obtained also require speed and accuracy with the help of a computer. Using or functioning a computer there must be a distributed program in it. The programs contained in the computer vary widely and each program must use an algorithm. Algorithm is a collection of commands to solve a problem gradually from start to finish. There are various algorithms that can be used to find the shortest route such as Breadth First Search algorithm, Depth First Search, A *, Hill Climbing and others. For that required comparison algorithm which is able to find the shortest route accurately and efficiently. In this journal, the algorithm to be compared is the genetic algorithm and greedy algorithm to find the shortest route on a map. Some aspects to be compared are aspects of the accuracy, speed, and complexity of genetic algorithms and greedy algorithms for the shortest route search.
\end{abstract}

Keyword: Algoritma Genetika, Algoritma Greedy, Rute terpendek, Perbandingan Algoritma

\section{Introduction}

Transportasi berperan terpenting bagi masyarakat. Saat ini perkembangan transportasi sangat pesat dan mengakibatkan bertambahnya volume kendaraan sehingga memicu terjadinya kemacetan. Luasnya jalan raya akan menyulitkan masyarakat dalam menemukan rute optimum, maka pencarian rute optimum menjadi masalah terbesar bagi masyarakat saat ini . Banyak jalan yang harus dilewati ketika akan menuju dari tempat satu ke tempat lain. Guna dari pemilihan jarak optimal ini yakni meminimalisir waktu serta biaya yang dikeluarkan dalam melakukan perjalanan tersebut. Beberapa masalah diatas dapat diminimalisir dengan menggunakan beberapa metode algoritma.

Dalam penelitian yang berjudul "Sistem Pencarian Hotel Berdasarkan Rute Perjalanan Terpendek Dengan Mermpertimbangkan Daya Tarik Wisata Menggunakan Algoritma Greedy" telah menghasilkan sistem yang dapat memberikan rekomendasi rute dan urutan perjalanan terpendek antara hotel dan daya tarik wisata berdasarkna algoritma greedy.

Penelitian dengan judul "Pencarian Rute Terpendek Menggunakan Algoritma Greedy" telah menghasilkan pencarian rute terpendek dari node A (kecamatan Ngaliyan) ke node L (kecamatan Sampangan) dengan menggunakan algoritma greedy. Rute dari node A ke node L yang paling optimal dengan jarak terpendek adalah rute A - B - D - G - I - K - J - L dengan jarak $12 \mathrm{~km}$.

Penelitian yang berjudul "Algoritma Greedy Untuk Menentukan Lintasan Terpendek" telah menghasilkan pencarian lintasan terpendek berdasarkan jarak dan waktu-waktu terjadinya kemacetan. Dimana sangat membantu masyarakat dalam mencari rute tercepat saat terjadi kemacetan dengan waktu yang efisien.

Dalam penelitian yang berjudul "Implementasi Algoritma Genetika Untuk Pencarian Rute Berdasarkan Waktu Tercepat Objek Wisata Di Kabupaten Ngawi" telah menghasilkan aplikasi pencarian rute tercepat dalam kemacetan dengan menggunakan algoritma genetika. Dimana sangat membantu masyarakat mencari rute menuju objek wisata di Kabupaten Ngawi.

Penelitian dengan judul "Penentuan Jarak Terpendek Pada Jalur Distribusi Barang Di Pulau Jawa dengan Menggunaka Algoritma Genetika" telah menghasilkan perangkat lunak dengan mencari rute pengiriman barang dengan waktu dan biaya perjalanan yang optimal. Pada data awal nilai fitness pada tahap inisialisasi dari kromosom adalah 931setelah melalui proses algoritma genetika menghasilkan nilai fitness 762 .

Penelitian yang berjudul "Penerapan Algoritma Genetika Dalam Menemukan Rute Terpendek" telah menghasilkan ada 63 tes yang menggunakan 6 titik lokasi. Itu hasil uji menggunakan nilai populasi $(10,15)$, 
crossover $(0,2,0,3,0,5,0,6,0,7,0,8)$, mutasi $(0,1,0,05,0,4,0,7)$ dan iterasi $(200.300 .400 .500)$ menunjukkan bahwa terpendek rute adalah $239,45 \mathrm{~km}$ dan waktu 6,65 . Algoritma tingkat akurasi $85,7 \%$ dan rute yang bisa dilewati adalah A - C - D - B - E - F - A.

Pada makalah ini, penulis akan membandingkan pemilhan rute tercepat menggunakan metode algoritma genetika dengan algoritma greedy. Diantara kedua metode tersebut manakah yang paling eifsien dalam pemilihan rute tercepat dengan tidak membuang waktu dan biaya.

\section{Research Method}

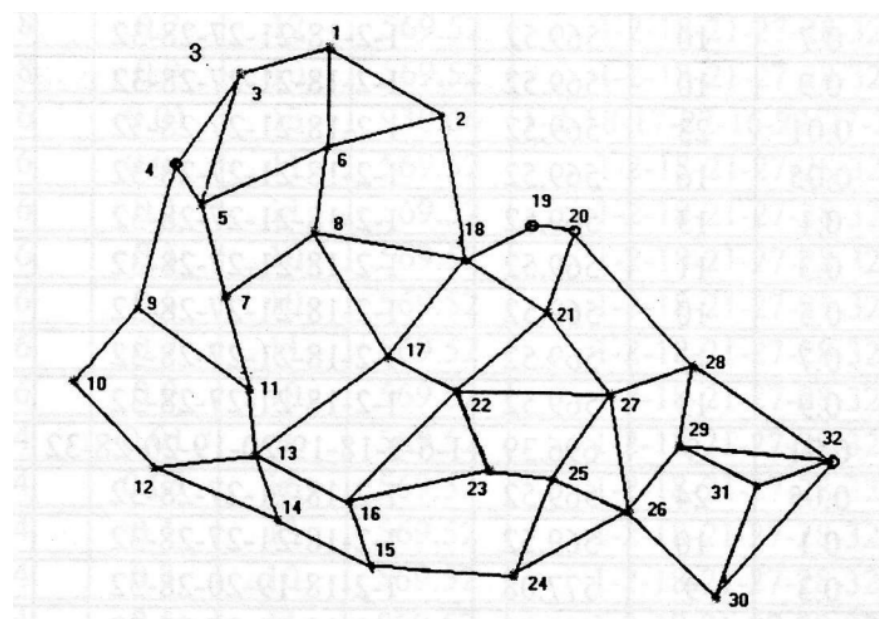

Gambar 1. Rute Masalah

\section{Perbandingan Algoritma}

Dari kasus yang telah ditentukan, akan dicari penyelesaian rute terpendek dari rute masalah yang ada dengan cara membandingkan dari beberapa aspek yang akan dibandingkan dari algoritma genetika dan algoritma greedy. Aspek yang kan dibandingkan adalah sebagai berikut:

1) Akurasi pencarian rute terpendek

Aspek yang akan dibandingkan pertama kali adalah dari segi akurasi atau ketepatan dalam mencari rute terpendek yang dihasilkan dari penyelesaian algoritma genetika dan algoritma greedy. Algoritma manakah yang dapat mencari rute terpendek dari permasalahan yang telah ditentukan.

2) Efisiensi pencarian rute terpendek

Perbandingan kedua adalah aspek efisiensi atau kecepatan dari algoritma genetika dan algoritma greedy dalam mencari rute terpendek. Algoritma manakah yang dapat menentukan rute terpendek dengan waktu yang singkat.

3) Kompleksitas pencarian rute terpendek

Dalam pencarian rute terpendek, hal yang diperlukan untuk pencarian tidak hanya jarak antara tiap node saja, akan tetapi juga ada hal lain yang dapat digunakan untuk menambah efisiensi pencarian rute terpendek. Oleh karena itu akan dibandingkan algoritma manakah yang mempunyai kompleksitas dalam mencari rute terpendek.

\section{Result and Analysis}

A. Algoritma Genetika

Algoritma genetika merupakan suatu metode pencarian yang didasarkan pada mekanisme dari seleksi dan genetika natural. Secara umum, blok diagram dari mekanisme kerja algoritma genetika ini adalah seperti yang terlihat pada Gambar 2 . 


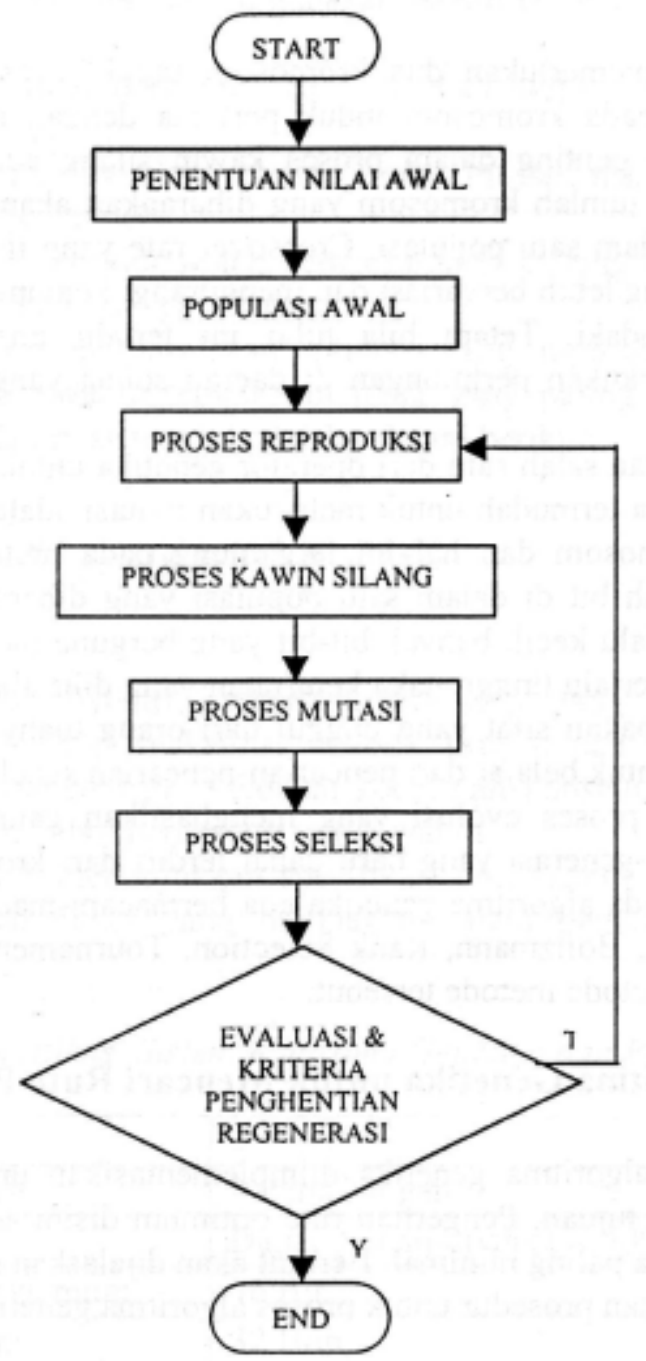

Gambar 2. Flowchart Algoritma Genetika

1) Prosedur Algoritma Genetika

- Prosedur Angka Acak Angka/random yang digunakan dalam algoritma genetika ini memakai fungsi yang telah disediakan oleh bahasa program pascal

- Prosedur Reproduksi Prosedur ini akan menduplikasi ulang kromosom induk secara lengkap sehingga menghasilkan turunan baru yang sama dengan induknya

- Prosedur Kawin Silang Prosedur ini akan memilih dua krornosom induk yang akan mengalami proses.kawin silang secara acak, kemudian menetukan satu atau dua titik potong secara acak pula. Setelah titik potong ini terpilih maka dilakukan proses penukaran informasi dari kedua kromosom itu berdasarkan titik potong yang telah ditentukan

- Prosedur Mutasi Prosedur mutasi yang akan digunakan adalah mutasi bit. Setiap bit dari kromosom tersebut akan mempunyai peluang sendiri untuk mengalami mutasi. Probabilitas terjadinya mutasi pada setiap bit ditentukan oleh nilai mutation rate

- Prosedur Seleksi Seleksi yang digunakan dalam penelitian ini adalah metode roulette-wheel. Dalam metode roulette-wheel, peluang setiap lcomosom untuk terseleksi sebanding dengan nilai obyektifnya. Semakin besar nilai obyektif, maka semakin besar peluang untuk terseleksi

- Prosedur Populasi Awal Prosedur ini akan membangkitkan sejumlah kromosom secara acak untuk membentuk populasi awal. Jumlah kromosom dalam satu polulasi dapat bervariasi sesuai dengan setting awal yang telah ditentukan.

- Prosedur Penghitungan Generasi Prosedur ini dibuat untuk memeriksa apakah kriteria berhenti dari algoritma genetika sudah dipenuhi atau tidak. Hal ini dilakukan dengan menghitung jumlah generasi sampai batas maksimum yang diberikan. Bila dalam jumlah generasi yang ditentukan tidak ada kromosom yang lebih baik maka algoritma genetika akan berhenti melakukan proses iterasi. 
Pengujian proses algoritma genetika dilakukan dengan melakukan perubahan nilai parameter yang digunakan, yaitu nilai crossover rate, nilai mutation rate maupun nilai jumlah lromosom per populasi. Percobaan dilakukan dengan mencari rute terpendek. Bentuk rute pengujian dapat dilihat pada Gambar 3. Pengujian yang dilakulan adalah mencari rute paling optimum dari titik spot menuju ke titik spot 32 .

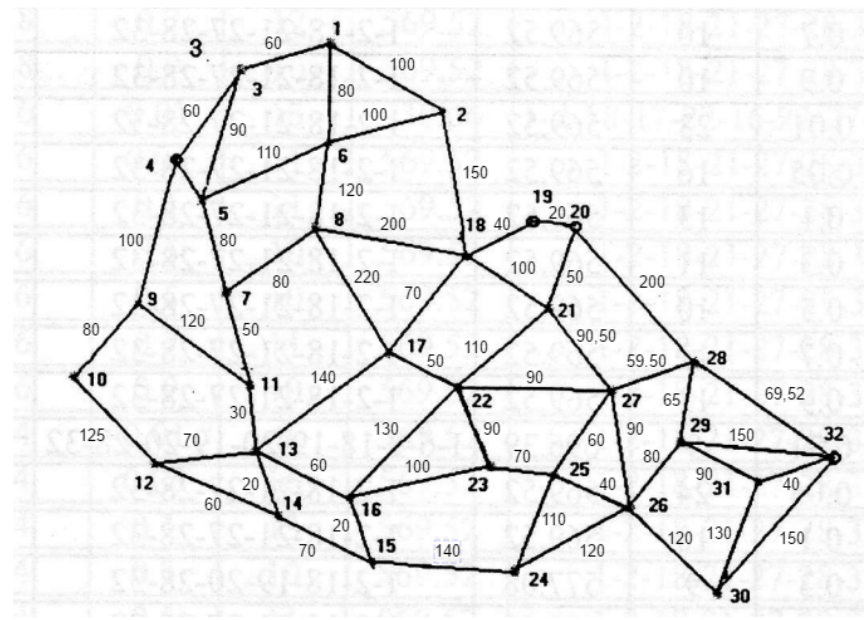

Gambar 3 Rute Masalah Algoritma Genetika

Melalui perhitungan secara manual didapatkan nilai obyektif yang terbaik adalah $569.52 \mathrm{~km}$ dan rute yang terpendek adalah rute dari spot 1 - 2 - 18 - 21 -27- 28 - 32. Hasil pengujian sistem yang paling sederhana, tanpa menggunakan syarat, juga menghasilkan nilai yang sama dengan perhitungan manual. Tabel 1 menunjukkan beberapa hasil pengujian yang telah dilakukan dari pengujian di atas tadi dengan menggunakan metode seleksi roulette-wheel.

3) Hasil Algoritma Genetika

Tabel 1. Hasil Pengujian

\begin{tabular}{|c|c|c|c|c|c|c|}
\hline No & $\begin{array}{l}\text { Nilai } \\
\text { Cross } \\
\text { over }\end{array}$ & $\begin{array}{c}\text { Nilai } \\
\text { Muta } \\
\text { si }\end{array}$ & $\begin{array}{l}\text { Wakt } \\
\mathrm{u}(\mathrm{dt})\end{array}$ & $\begin{array}{c}\text { Obyekt } \\
\text { if } \\
\text { Terbaik }\end{array}$ & Rute & $\begin{array}{c}\text { Akhir } \\
\text { Gener } \\
\text { asi }\end{array}$ \\
\hline 1 & 1 & 0.01 & 24 & 569.52 & $1-2-18-21-27-28-32$ & 2745 \\
\hline 2 & 1 & 0.05 & 13 & 569.52 & $1-2-18-21-27-28-32$ & 1479 \\
\hline 3 & 1 & 0.1 & 13 & 569.52 & $1-2-18-21-27-28-32$ & 1408 \\
\hline 4 & 1 & 0.3 & 10 & 569.52 & $1-2-18-21-27-28-32$ & 1036 \\
\hline 5 & 1 & 0.5 & 14 & 569.52 & $1-2-18-21-27-28-32$ & 1447 \\
\hline 6 & 1 & 0.7 & 10 & 569.52 & $1-2-18-21-27-28-32$ & 1164 \\
\hline 7 & 1 & 0.9 & 11 & 569.52 & $1-2-18-21-27-28-32$ & 1220 \\
\hline 8 & 0.9 & 0.01 & 11 & 651.62 & $\begin{array}{l}1-2-18-19-20-21-27-28- \\
32\end{array}$ & 1188 \\
\hline 9 & 0.9 & 0.05 & 10 & 569.52 & $1-2-18-21-27-28-32$ & 1109 \\
\hline 10 & 0.9 & 0.1 & 13 & 569.52 & $1-2-18-21-27-28-32$ & 1447 \\
\hline 11 & 0.9 & 0.3 & 14 & 569.52 & $1-2-18-21-27-28-32$ & 1443 \\
\hline 12 & 0.9 & 0.5 & 10 & 569.52 & $1-2-18-21-27-28-32$ & 1138 \\
\hline 13 & 0.9 & 0.7 & 11 & 577.08 & $1-2-18-21-27-28-32$ & 1141 \\
\hline 14 & 0.9 & 0.9 & 10 & 569.52 & $1-2-18-21-27-28-32$ & 1139 \\
\hline 15 & 0.8 & 0.01 & 11 & 569.52 & $1-2-18-21-27-28-32$ & 1257 \\
\hline 16 & 0.8 & 0.05 & 12 & 569.52 & $1-2-18-21-27-28-32$ & 1348 \\
\hline 17 & 0.8 & 0.1 & 10 & 569.52 & $1-2-18-21-27-28-32$ & 1065 \\
\hline 18 & 0.8 & 0.3 & 10 & 569.52 & $1-2-18-21-27-28-32$ & 1118 \\
\hline 19 & 0.8 & 0.5 & 13 & 569.52 & $1-2-18-21-27-28-32$ & 1368 \\
\hline 20 & 0.8 & 0.7 & 10 & 569.52 & $1-2-18-21-27-28-32$ & 1043 \\
\hline 21 & 0.8 & 0.9 & 10 & 569.52 & $1-2-18-21-27-28-32$ & 1030 \\
\hline 22 & 0.6 & 0.01 & 23 & 569.52 & $1-2-18-21-27-28-32$ & 2788 \\
\hline 23 & 0.6 & 0.05 & 16 & 569.52 & $1-2-18-21-27-28-32$ & 1742 \\
\hline 24 & 0.6 & 0.1 & 13 & 569.52 & $1-2-18-21-27-28-32$ & 1384 \\
\hline 25 & 0.6 & 0.3 & 11 & 569.52 & $1-2-18-21-27-28-32$ & 1207 \\
\hline 26 & 0.6 & 0.5 & 10 & 569.52 & $1-2-18-21-27-28-32$ & 1095 \\
\hline 27 & 0.6 & 0.7 & 11 & 569.52 & $1-2-18-21-27-28-32$ & 1175 \\
\hline 28 & 0.6 & 0.9 & 13 & 569.52 & $1-2-18-21-27-28-32$ & 1399 \\
\hline 29 & 0.4 & 0.01 & 9 & 696.39 & $\begin{array}{c}1-6-2-18-19-20-19-20- \\
28-32\end{array}$ & 1036 \\
\hline 30 & 0.4 & 0.05 & 24 & 569.52 & $1-2-18-21-27-28-32$ & 2700 \\
\hline 31 & 0.4 & 0.1 & 10 & 569.52 & $1-2-18-21-27-28-32$ & 1092 \\
\hline 32 & 0.4 & 0.3 & 9 & 577.08 & $1-2-18-21-20-28-32$ & 1016 \\
\hline 33 & 0.4 & 0.5 & 10 & 569.52 & $1-2-18-21-27-28-32$ & 1093 \\
\hline
\end{tabular}




\begin{tabular}{|l|c|c|c|c|c|c|}
\hline 34 & 0.4 & 0.7 & 12 & 569.52 & $1-2-18-21-27-28-32$ & 1279 \\
\hline 35 & 0.4 & 0.9 & 16 & 569.52 & $1-2-18-21-27-28-32$ & 1628 \\
\hline 36 & 0.1 & 0.01 & 11 & 634.97 & $1-2-18-21-27-28-32$ & 1209 \\
\hline 37 & 0.1 & 0.05 & 12 & 569.52 & $1-2-18-21-27-28-32$ & 1309 \\
\hline 38 & 0.1 & 0.1 & 10 & 569.52 & $1-2-18-21-27-28-32$ & 1089 \\
\hline 39 & 0.1 & 0.3 & 11 & 569.52 & $1-2-18-21-27-28-32$ & 1237 \\
\hline 40 & 0.1 & 0.5 & 10 & 569.52 & $1-2-18-21-27-28-32$ & 1116 \\
\hline 41 & 0.1 & 0.7 & 12 & 569.52 & $1-2-18-21-27-28-32$ & 1349 \\
\hline 42 & 0.1 & 0.9 & 15 & 569.52 & $1-2-18-21-27-28-32$ & 1676 \\
\hline
\end{tabular}

\section{B. Algoritma Greedy} langkah:

Algoritma greedy adalah algoritma yang memecahkan masalah langkah demi langkah, pada setiap

1. Mengambil pilihan yang terbaik yang dapat diperoleh saat itu

2. Berharap bahwa dengan memilih optimum lokal pada setiap langkah akan mencapai optimum global. Algoritma greedy mengasumsikan bahwa optimum lokal merupakan bagian dari optimum global.

\section{1) Lintasan Terpendek (Shortest Path)}

Lintasan terpendek adalah lintasan minimum yang diperlukan untuk mencapai suatu tempat dari tempat tertentu. Lintasan minimum yang dimaksud dapat dicari dengan menggunakan graf. Graf yang digunakan adalah graf yang berbobot, yaitu graf yang setiap sisinya diberikan suatu nilai atau bobot. Dalam kasus ini, bobot yang dimaksud berupa jarak .

Algoritma greedy untuk mencari lintasan terpendek dapat dirumuskan sebagai berikut:

1. Perikasa semua sisi yang langsung bersisian dengan simpul a. Pilih sisi yang bobotnya terkecil.

Sisi ini menjadi lintasan terpendek pertama, sebut saja L(1).

2. Tentukan lintasan terpendek kedua dengan cara berikut: (i) hitung: d(i) = panjang $L(1)+$ bobot sisi dari simpul akhir L(1) ke simpul i yang lain (ii) pilih d(i) yang terkecil Bandingkan d(i) dengan bobot sisi (a, i). Jika bobot sisi (a, i) lebih kecil daripada d(i), maka $\mathrm{L}(2)=\mathrm{L}(1) \mathrm{U}$ (sisi dari simpul akhir L(i) ke simpul i) 3. Dengan cara yang sama, ulangi langkah 2 untuk menentukan lintasan terpendek berikutnya.

2) Penyelesaian Masalah Rute

Rumusan masalah saat ini adalah bagaimana menentukan rute optimum dari Node 1 ke Node 32 dengan menggunakan Algoritma Greedy sehingga mempunyai jarak terpendek. Graf dari node 1 sampai dengan node 32 dan bobot tiap-tiap sisi (bobot menyatakan jarak dari setiap node satu ke node lain) seperti ditunjukkan pada gambar 4 berikut ini :

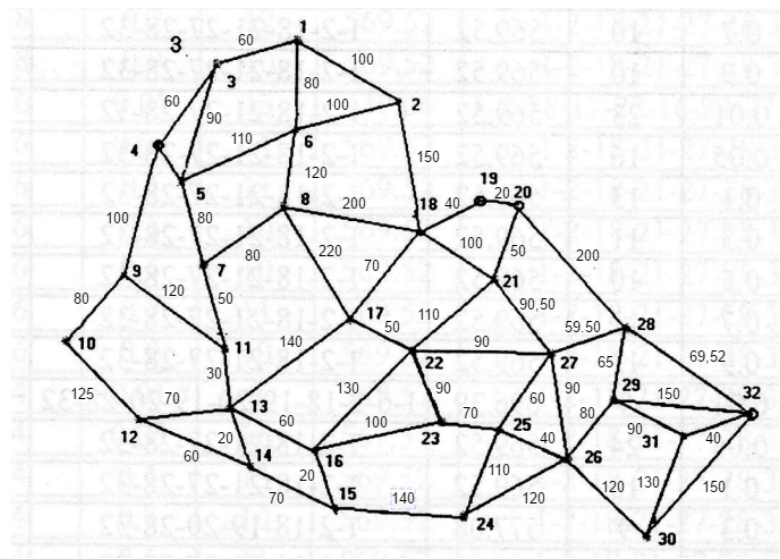

Gambar 4 Rute Masalah Algoritma Greedy

Berdasarkan proses algoritma Greedy, didapatkan rute yang paling optimal dari node 1 ke node 32 adalah rute 1-3 - 4 - 5 - 7 - 11- 13-16-23-25-25-26-29-28 - 32 dengan jarak 834km.

\section{Conclusion}


Berdasarkan perbandingan yang telah dilakukan, maka dapat diambil kesimpulan sebagai berikut:

1. Rute yang paling terpendek didapatkan dengan menggunakan algoritma genetika yaitu $569,52 \mathrm{~km}$, sedangkan algoritma greedy menunjukkan rute optimum sejauh $834 \mathrm{~km}$.

2. Algoritma genetika memiliki tingkat akurasi yang tinggi dalam mencari rute terpendek dengan jumlah node yang memiliki banyak percabangan serta bobot yang bervariasi.

3. Algoritma greedy kurang efisien saat digunakan untuk mencari rute terpendek dengan banyak node yang bercabang karena algoritma greedy tergantung pada bobot setiap simpulnya, sehingga rute yang dihasilkan kurang optimal.

4. Proses pencarian rute menggunakan algoritma genetika membutuhkan waktu yang cukup lama dibandingkan dengan algoritma greedy karena harus melalui banyak tahapan proses untuk mendapatkan rute terpendek.

\section{Acknowledgements} membantu.

Artikel ini tersusun sebagai syarat tugas project mata kuliah. Terimakasih untuk semua teman yang

\section{References}

[1] Annasir, Agus wahyu. 2013. Implementasi Algoritma Genetika Untuk Pencarian Rute Berdasarkan Waktu Tercepat Objek Wisata Di Kabupaten Ngawi. Universitas Muhammadiyah Surakarta.

[2] Joni I Dewa Made Adi Bagaskara, dan Nurcahyawati, Vivine. 2012. Penentuan Jarak Terpendek Pada Jalur Distribusi Barang Di Pulau Jawa Dengan Menggunakan Algoritma Genetika. Jurnal Nasional Pendidikan Teknik Inormatika, Vol 1, No. 3, Desember 2012. STMIK STIKOM Indonesia dan STMIK STIKOM Surabaya.

[3] Fallo Diana, Santoso Alb.Joko, dan Budiyanto Djoko. 2015. Penerapan Algoritma Genetika Dalam Menemukan Rute Terpendek. Magister Informatika, Fakultas Teknologi Industri, dan Universitas Atma Jaya Yogyakarta.

[4] Herli Audrey Maximillian, Raharja Indra Kharisma, dan Purbandini. Sistem Pncarian Hotel Berdasarkan Rute Perjalanan Terpendek Dengan Mempertimbangkan Daya Tarik Wisata Menggunakan Algoritma Greedy. Journal o Information System Engineering and Business Intelligence, Vol. 1, No. 1, April 2015. Program Studi SIstem Informasi, Fakultas Sains dan Teknologi, Universitas Airlangga.

[5] Hayati Enty Nur, da Yohanes Antoni. 2014. Pencarian Rute Terpendek Menggunakan Algoritma Greedy. Program Studi Teknik Industri dan Universitas Stikubank Semarang.

[6] Deindal Irvan Prama, Ariesanda Boyke, dan Christoforus. 2012. Algoritma Greedy Untuk Menentukan Lintasan Terpendek. Departemen Teknik 